\title{
COMMUNITY HEALTH EDUCATION THROUGH NON-FORMAL EDUCATION IN PAKISTAN
}

\author{
1)Muhammad Ajmal \\ 2)Farzana M.Phil \\ 1)Assistant Professor Allama lqbal Open University Islamabad, Pakistan \\ 2) Scholar Allama Iqbal Open University Islamabad, Pakistan \\ drajmal@aiou.edu.pk
}

\begin{abstract}
ABSTRAK
Pendidikan kesehatan merupakan komponen integral dari pelayanan kesehatan primer. Petugas kesehatan wanita menyediakan berbagai layanan kesehatan kepada masyarakat di Pakistan. Mereka harus menyadari dan dilatih tentang aspek kuratif dan preventif pelayanan kesehatan primer. Ada kebutuhan mendesak untuk mendidik dan mengatur kesehatan pelatihan pendidikan untuk petugas kesehatan wanita. Jadi studi ini dirancang pada "pendidikan kesehatan masyarakat melalui pendidikan non-formal". Populasi dari penelitian ini adalah petugas kesehatan wanita, master trainer dan masyarakat. Tanggal dikumpulkan melalui lima titik skala Likert dan beberapa pertanyaan terbuka untuk petugas kesehatan wanita dan master trainer dan wawancara checklist untuk masyarakat. Hasil penelitian menunjukkan bahwa petugas kesehatan wanita tidak memiliki pengetahuan yang cukup tentang kesehatan dan penyakit umum. Ada cukup pelatihan in-service bagi petugas kesehatan wanita untuk meningkatkan keterampilan dan pengetahuan mereka untuk hasil yang lebih baik. Studi direkomendasikan bahwa selain program pelatihan yang ada, sesi kesehatan pelatihan harus diatur melalui videoconference / telekonferensi, kursus pelatihan online, media sosial, TV / program Radio FM, literatur terbaru, program CD yang direkam untuk petugas kesehatan wanita.
\end{abstract}

Kata kunci: pelatihan pendidikan kesehatan, pendidikan non-formal, perawatan kesehatan primer, petugas kesehatan wanita.

\begin{abstract}
Health education is an integral component of primary health care services. Lady health workers provide a broad range of health services to the communities in Pakistan. They should be aware and trained about curative and preventive aspects of primary health care services. There is an urgent need to educate and organize health educational trainings for Lady Health Workers. So this study was designed on "community health education through Non-formal education". The population of this study was lady health workers, master trainers and community people. Date was collected through five point Likert scale and some openended questions for lady health workers and master trainers and interview checklist for community people. Results showed that the lady health workers do not have sufficient knowledge about health and common diseases. There are insufficient in-service trainings for lady health workers to enhance their skill and knowledge for better outcomes. Study
\end{abstract}


recommended that in addition to existing training program, training health sessions should be arranged through videoconferencing/ teleconferencing, online training courses, social media, TV/ FM Radio programs, latest literature, CD recorded programs for lady health workers.

Keywords: health education trainings, lady health workers, non-formal education, primary health care.

Being a developing country Pakistan has to face various challenges to attain the targets of Millennium Development Goals (MDG's) at national level. Lady Health Workers are playing a vital role to fulfill these challenges but the lady health workers have insufficient knowledge and skills to educate the community people. There is a dire need to educate and organize health educational trainings for Lady Health Workers in this country. They should be aware on the curative and preventive aspects of care related to newborn, maternal, tuberculosis, malaria, HIVIAIDs, Sexual Transmitted Diseases, Hepatitis $B, C$ and Dengue etc. There is a huge gap between in-service education of Lady Health Worker and provision of health services to the communities which the formal system cannot cope with the demand. The objective of this study was to examine the existing status of in-service education of lady health workers and problems faced during their performance and proposed a new model of in-service education training program for Allama lqbal Open University (AIOU).

\section{National program for family planning \& Primary health care}

Lady health workers (LHW's) program is globally recognized as the most excellent model for the provision of health care services at health facilities. This program was started in 1994. More than half of the country is covered by the lady health workers of National Program. Dream of this program is to overcome the gap between the Hospitals and Communities through delivery of quality Integrated Primary health care facilities at door-to-door of the people. LHW's program to present Primary Health Care services to the people, hence improve neonatal, maternal and child health. According to 1999, National Program recruits Females and trained them for the delivery of essential health services in their community. These local home visitors had an encouraging impact on child spacing, health practices of mothers, exclusive breastfeeding till six month and prevention of diarrhea. The outcomes included child growth monitoring, childhood vaccination rates and control of diarrhea among and poor households and lower income. (National Program Report, (2011)

\section{Responsibilities of lady health workers}

Abroad range of services of lady health workers which present in their community describe

by Zahid (2002) Curriculum for Trainer of National Program for primary health care: Islamabad; Ministry of Health.

1. To register all eligible couples, in their catchment area and distributes contraceptives for family planning methods.

2. To facilities and encourage antenatal and post-natal care by (SBA) skilled birth attendant.

3. To provide services for expanded program Immunization (EPI).

4. To provide necessary referral and treatment for children with diarrhea and acute respiratory disease. 
5. To encourage exclusive breastfeeding till six month and promote precaution of basic hygiene.

6. To offer knowledge how to prevent from TB and malaria and also contribute in DOTS organization.

7. To offer knowledge how to control and prevent about sexual transmitted diseases and HIVIAIDS.

8. To organize and present a monthly data report to the concerned health facility.

9. To provide medicines in their catchment area.

10. Participation in polio eradication, monitoring for nutrition, referral system, deworming, Tuberculosis (DOTS) program.

\section{In-service training programs in International Scenario Project Helping Hands Program}

Project Helping Hands has developed culturally appropriate education materials for all the countries served. In this training program, Cambodia, Kenya, Liberia, Philippines, Sudan, Uganda had been participated. The primary purpose of Project Helping Hands (PHH's) volunteer clinics is not to provide temporary health care, but rather preventive health education. The teaching happens both one-on-one and in groups in the clinic lines. (WHO, 2010)

\section{Sub-Saharan Africa in-service training program}

In sub-Saharan Africa, in-service training programs appear to be administered primarily by either NGOs or private-public partnerships. (Funes, 2012) Curricula for in-service training programs are provided to Community Health Workers, refresher training and new content focused on a specific disease or treatment method. (iHeed Institute, 2013)

\section{Zimbabwe in-service training program}

The Zimbabwe National Family Planning Council and the Zimbabwe Ministry of Health established a community-based distribution program. Lady health workers now receive in-service training with up-to-date information on HIVIAIDS and STD prevention, referral practices, and counseling methods to communities in rural Zimbabwe. (USAID, 2004)

\section{Nepal in-service training program}

Nepal's Female Community Health Volunteer (FCHV) Program was created to improve access to health care in Nepal. FCHVs receive a refresher training on content they learned in their initial training as hygiene, family planning, diarrheal disease, and Integrated Management of Childhood IIIness. (JHPIEGO, 2003)

\section{Sri Lanka in-service training program}

The need to develop communication skills was largely ignored and therefore, fifty percent of volunteers felt that they needed to be taught methods of communication, so that they could transmit health messages more easily (Walt, 1989).

\section{India in-service training program}

In-service training in India provided by governments, NGOs, or a partnership between them. In-service training in India addressed training for support and treatment of mental health issues, predominantly depression, mental health disorders, mental health first aid, mental health promotion, 
and practice-based skills. (Armstrong et al., 2011).

United States in-service training program

Village Health Works aims to bring health to the rural village of Kigutu and surrounding areas through collaborative efforts between the community and people in the U.S. A Community Center, which will be used for training Community Health Workers and holding community engagement events where people will learn about nutrition, food security, and basic health promotion. (USAID, 2006)

\section{Pakistan in-service training program}

Pakistan's Lady Health Worker (LHW) Program was established to create an influx of 100,000 Community Health Workers (CHWs) by 2005. They are required to participate in a 15 month training program where they spend three months of their time in the classroom and 12 months receiving experiential training in the field. LHWs are educated in maternal and child health, including family planning, HIVIAIDS, and the treatment of minor illnesses.

\section{Gaps in-service training program in Pakistan}

1. The only gap identified in curricula was the lack of emphasis on communication skills. (Haq \& Hafeez, 2009)

2. Lack of coordination with other service provider and lady health workers. (Pathfinder International, ( 2011).

3. Trainings are not supportive and not attractive to the Lady Health Workers to encourage the learning process. (Joynes, 2011).

4. No use of technology in lady health worker training programs. (Funes, 2012)

5. In-service training programs fall into two categories:

- Refresher courses and

- Instruction on new material. (WHO, (2014)

Incorporating these best practices into new or existing in-service training programs could address some of the training gaps and ultimately enhance lady health workers competency. The lady health workers can play an effective role to provide the basic health needs at the door-steps. There is a big gap between the basic health facilities and the common people, all this due to lack of awareness, coordination and cooperation between the health facility staff and common people. Lady health workers do all these tasks very well but there is a dire need of refresher trainings to enhance the knowledge about diseases, how to prevent and cure from these fatal diseases. Formal system and Government could not overcome these problems.

\section{Research Questions}

1. What is existing status of in-service education of lady health workers?

2. Is the present system of in-service education sufficient for fulfilling the needs of Lady Health Workers to run the program effectively?

3. What are the problems hindering the Lady Health Workers to disseminate their duties?

4. What is the need to conduct a need analysis of in-service education program for Lady Health Workers to be run through Non-Formal Education?

5. What are the strategies to improve the in-service education program for Lady Health Workers through Non Formal Education? 


\section{Methodology}

Table 1. Population and Sample.

\begin{tabular}{lrrcl}
\hline Category & Population & Sample & Sample Size & Sampling Technique \\
\hline Lady health Workers & 2.500 & 250 & $10 \%$ & Simple Random Sampling \\
District Master Trainers & 10 & 5 & $50 \%$ & Simple Random Sampling \\
Community People & 3.232 .307 & 250 & - & Simple Random Sampling \\
\hline
\end{tabular}

The study was descriptive in nature. A survey was carried out in which lady health workers, master trainers and community people took part. Questionnaire was developed on five point Likert scale and two open-ended questions for lady health workers, master trainers and interview protocol for community people. The questions were developed on the basis of health indicators of lady health workers. The instrument was validated and administered personally. The simple frequency, percentage and mean score was used to describe perception of the respondents. The interview protocol was used to get understanding of the community people and analyzed the data by applying the percentage.

\section{Results}

This section deals with the interpretation and discussion of results. It presents analysis on the perceptions of lady health workers, master trainers about the gaps of in-service education of lady health workers and the problems faced by lady health workers during their job performance. It also presents analysis of interview protocol of community people.

Table 2. Analysis of Lady Health Workers (LHWs) \& Master Trainers (DMTs) About Health Education Program.

\begin{tabular}{|c|c|c|}
\hline \multirow{2}{*}{ Statements } & \multicolumn{2}{|c|}{ Mean score } \\
\hline & LHWs & DMTs \\
\hline $\begin{array}{l}\text { Existing health educational trainings are sufficient to prepare the effective } \\
\text { lady health workers in the community. }\end{array}$ & 2,23 & 2,40 \\
\hline $\begin{array}{l}\text { I have sufficient knowledge about the basic health for the awareness of } \\
\text { community people. }\end{array}$ & 2,22 & 2,40 \\
\hline I am well aware about modern methods of family planning & 2,41 & 2,40 \\
\hline $\begin{array}{l}\text { I have sufficient knowledge to increase the vaccination rate for under } 2 \text { years } \\
\text { old children. }\end{array}$ & 3,61 & 3,60 \\
\hline $\begin{array}{l}\text { I can effectively motivate the pregnant women to deliver from the skilled birth } \\
\text { attendant (safe delivery). }\end{array}$ & 2,22 & 2,40 \\
\hline I can easily convince the mothers about exclusive breast feeding till 6 month. & 2,23 & 2,40 \\
\hline I can correct the misconceptions of community people about polio vaccine. & 2,34 & 2,30 \\
\hline $\begin{array}{l}\text { I have sufficient information about common health problems for the } \\
\text { awareness of people. }\end{array}$ & 2,01 & 2,20 \\
\hline $\begin{array}{l}\text { I am getting benefited regularly from health educational trainings on } \mathrm{CD} \text { at } \\
\text { union council. }\end{array}$ & 1,98 & 2,00 \\
\hline $\begin{array}{l}\text { I have been fully benefited from TV/FM radio programs \& online training } \\
\text { courses. }\end{array}$ & 1,98 & 1,80 \\
\hline I have been trained through latest literature and Magazines at home. & 2,32 & 2,20 \\
\hline
\end{tabular}


According to above analysis mean sores of lady health workers and master trainers are showing that the Lady Health workers had not sufficient knowledge to motivate the women about family planning, exclusive breastfeeding, misconceptions about polio vaccine, and antenatal, postnatal checkup, delivered by skilled persons. They also had not able to answer the questions about common health problems before the community people. Lady health workers are not getting benefitted from CD recorded programs, TV/FM Radio training programs, latest literature and Magazines.

Table 3. Literature and Magazines.

\begin{tabular}{llc}
\hline \multicolumn{1}{c}{ Problems } & LHWs & DMTs \\
\hline - & \begin{tabular}{l}
\multicolumn{1}{c}{ Due to traveling, transport problems, could not access the training } \\
centers.
\end{tabular} & $70 \%$ \\
- Lack of information about chronic \& common diseases, not able to & $78 \%$ & $60 \%$ \\
$\quad \begin{array}{l}\text { answer the community. } \\
\text { Data transformation, record keeping system is slow \& poor from LHWs. }\end{array}$ & $80 \%$ & $80 \%$ \\
- Absence of incentive/TA/DA, increase LHWs financial constraints, & $84 \%$ & $80 \%$ \\
could not get trainings. & $78 \%$ & $80 \%$ \\
- LHWs are not full command over common diseases. & $78 \%$ & $60 \%$ \\
\hline
\end{tabular}

According to the above Table 3 some problems faced by lady health workers during their job performance were financial problems (absence of TA/DA), traveling problems, lady health workers could not access the training centers. Lack of information about chronic \& common diseases, family planning, lady health workers could not able to answer the community. Data transformation and record keeping system is also slow and poor from Lady health workers.

Table 4. Analysis of open-ended questions

\begin{tabular}{|c|c|c|}
\hline Suggestions & LHW & DMT \\
\hline $\begin{array}{l}\text { To improve the in-service education program latest literature, } \\
\text { brochures, drop cards, pamphlets must be provided at their homes. }\end{array}$ & $86 \%$ & $100 \%$ \\
\hline $\begin{array}{l}\text { - Videoconferencing/ Teleconferencing on common diseases \& family } \\
\text { planning should be conducted at health facility level. }\end{array}$ & - & $80 \%$ \\
\hline $\begin{array}{l}\text { - Use of social media like Facebook, What's App, Websites, Email, SMS } \\
\text { for quick data transformation \& record keeping. }\end{array}$ & - & $80 \%$ \\
\hline $\begin{array}{l}\text { - Refresher training courses on CD recorded programs about family } \\
\text { planning should be arranged at union council level. }\end{array}$ & $100 \%$ & \\
\hline $\begin{array}{l}\text { - Recorded programs \& practice on safe delivery and antenatal should } \\
\text { be provide at Basic Health Unit. }\end{array}$ & $80 \%$ & $80 \%$ \\
\hline
\end{tabular}

According to the above Table 4 Some suggestions from lady health workers and master trainers, to improve the in-service education program latest literature, brochures, drop cards, pamphlets must be provided at their homes, Videoconferencing/ Teleconferencing on common diseases \& family planning should be conducted at health facility level, social media should be used like what's App, SMS, Facebook, Websites, Email for data transformation and record keeping. 
Refresher training courses on CD recorded programs about family planning, safe delivery and antennal checkup should be arranged at union council/BHU level.

Table 5. Lady Health Workers and Master Trainers

\begin{tabular}{|c|c|}
\hline Interview protocol & Percentage \\
\hline $\begin{array}{l}\text { - Lady health workers provide services like family planning, vaccination of } \\
\text { children \& pregnant women }\end{array}$ & $78 \%$ \\
\hline - Provide protective measures about Dengue, measles and family health & $76 \%$ \\
\hline - LHWs should train in antenatal care and Safe delivery. & $51 \%$ \\
\hline - LHWs refer the community people to hospitals in case of emergency. & $40 \%$ \\
\hline $\begin{array}{l}\text { - Due to } 24 \text { hours service \& time problem and provide alternative ways for } \\
\text { trainings. }\end{array}$ & $52 \%$ \\
\hline - Govt. should provide basic health information at their homes. & $78 \%$ \\
\hline
\end{tabular}

According to the above Table 5 opinion of community people show that the lady health workers provide services like family planning, vaccination of children and pregnant women. They also provide protective measures about Dengue, measles, and family health and also should be train in antenatal \& safe delivery. Lady health workers also refer people to hospitals in case of emergency. According to community people, due to 24 hours service \& time problem and provide alternative ways for trainings and Govt. should provide basic health information at their homes.

\section{Conclusion and Discussion}

Existing in-service training program alone has not the capacity to prepare the effective lady health workers and also failed to educate the community people about health problems. MDGs were attained in 2000 and fix the targets of primary health care but not achieved till timeline 2015. Moreover performance of LHW's was not up to the mark. Hurdles faced by LHW's are still there viz insufficient budget for training, time constraint, insufficient knowledge skill, traveling \& transport problem, 24 hours service of LHW's, financial problems faced by LHWs and socio-cultural problems. There is a dire need of in-service health trainings for lady health workers to educate the community people. So there should be some alternative/supplemental Non-formal education mechanism for inservice lady health workers to enhance their knowledge, skill and resultantly considerable performance.

\section{Recommendations}

1. In addition to exiting training programs, training health sessions should be arranged about family planning, common diseases, breast feeding, safe delivery, polio vaccine etc. at Union Council level (health facilities) through videoconferencing/Teleconferencing. Laptops and Multimedia should be provided and trained staff must be recruited for operating/management.

2. For the correctness of misconceptions about Polio vaccine, in the monthly awareness health sessions, the participation of religious leaders, political members, support group leaders and influential community persons must be ensure, trained them and get their support to motivate the community people.

3. Refresher trainings on family planning and breastfeeding should be conducted at health facility center. Colorful leaflets, pamphlets, drop cards should be distributed during training sessions. 
Precise, comprehensive and informative massages should be conveyed by using AV aids and demonstration for counselling the community people about family planning.

4. TV/FM Radio programs \& Online training courses must be arranged for capacity building of lady health workers to make their performance effective in the community. Schedules of TV/FM Radio programs must be provided at start of the month and these programs may be redesigned/rescheduled in the light of the feedback provided by LHWs in monthly review meetings.

5. Magazines, latest literature, brochures, drop cards about health massages and problems should be published and provided on monthly basis at their homes/during monthly meetings.

6. CD recorded programs and practical trainings about new-born care, antenatal care, postnatal care, Vaccination Program, danger signs during pregnancy \& labor etc. should be provided at health facility level along-with Laptops/computers.

7. Use of social media like Facebook, What's App, Websites, Email, and SMS for data transformation \& record keeping, android phones/Tabs should be provided at BHU/RHC level. Program indicators should be updated and analyzed online.

8. As Allama Iqbal Open University has very vast experience of provision of Non-Formal Education spread over years, so it should take initiative of designing and implementation of in-service training programs to enhance knowledge and skill of lady health workers through Non- Formal Education.

\section{REFERENCES}

Armstrong, G. (2011). A mental health training program for community health workers. India: Int J Ment Health Syst. 17.

Funes, R. (2012). Preparing the next generation of community health workers: The power of technology for training. Cork, Ireland: iHeed Institute.

Haq, Z., \& Hafeez, A. (2009). Knowledge and communication needs assessment of community health workers in a developing country. Islamabad.

iHeed Institute. (2013). Revolutionizing global health education and training. Cork, Ireland: iHeed Institute.

JHPIEGO. (2003). Focus on community-based health volunteers in selected areas. Nepal.

Joynes, C. (2011). Distance learning for health. London: London.

National Program Report. (2011). Family planning and primary health care Pakistan., Islamabad: $\mathrm{MOH}$.

Pathfinder International. (2011). Integrating family planning and HIV. An water town, MA: Pathfinder International.

USAID. (2004). Integrating HIV services in local family planning. Washington: USAID.

USAID. (2006). Village health works innovations. United States: USAID.

Walt, G. (1989). Are large-scale volunteer community health worker programs feasible? Sri Lanka.

WHO. (2010). Project helping hand. Cambodia: University of Puthisastra.

WHO. (2014). Pakistan, Health systems strengthening. WHO.

Zahid, M. (2002). Curriculum for trainers of national program for family planning \&primary health care. Islamabad: Ministry of Health. 